\title{
PARTNERSHIP OF PARENTS AND MADRASAH TO REALIZE THE QUALITY OF EDUCATION
}

\author{
Raden Bambang Sumarsono \\ Department of Educational Management, State University of Malang, Indonesia \\ raden.bambang.fip@um.ac.id
}

\begin{abstract}
This study aims to describe: (1) parent and school partnership model, and (2) strategy to build partnership with parents. This research uses qualitative research type with phenomenology approach. Research design using case study. Data collection was conducted through in-depth interviews, observations, and related documentation studies that were under the theme of this study. Data analysis using description analysis. The results of the study show that: (1) parent-madrasah partnership forms, including (a) parental education, (b) voluntary activities, and (c) familial models; And (2) strategies for building partnerships with parents, including (a) strengthening two-way communication, (b) strengthening parent associations through class associations, (c) provision of excellent school programs, and (d) creating positive school climates .
\end{abstract}

Keyword: partnership form, partnership building strategy

\section{INTRODUCTION}

School quality is a school that is able to function all the components effectively and efficiently in order to create a conducive learning so that the goal of education is achieved. Education in elementary school is the main foundation that needs to get serious attention, meaning to get higher quality of education, it must start with the creation and formation of a qualified elementary school. This is in accordance with the opinion expressed by [15], that the quality of primary school education will form a good education (junior high school, senior high school, and college) is solid and quality. Creating quality schools is a process that requires strong commitment and cooperation from all school stakeholders [14]. The harmonious relationship between school and parent will bring the school towards the achievement of quality.

To realize a quality school, the need for synergy between schools and parents. Schools can not stand alone in meeting all the needs and development of students, therefore a meaningful involvement of the parents is always required. School and parents partnerships in creating quality schools need to be improved. With the establishment of a harmonious relationship between school and parents, then the participation of parents in realizing the quality of education will be realized. The results of Wolf [2] confirmed that there is a very significant correlation (0.80) between the family environment with the learning achievement of children. Talking about the relationship between parental participation and student achievement in school [4] mentions that there is a positive relationship between student achievement and parents' satisfaction with school. This indicates that the pattern of partnership between the family (parents) is very influential in achieving the quality of school.

The results of [5] showed a link between parental involvement and the achievement of students' reading outcomes at school. Another finding from [9] shows that parental involvement in school activities has a positive effect on the progress and development of student learning. This indicates that both academic and non-academic achievement will increase when there is participation from parents. Therefore, the mobilization of partnerships with parents is expected to synergistically lead to a goal of improving the quality of education.

\section{METHODS}

This research uses qualitative approach with descriptive research design, case study type. Based on the research design undertaken, the presence of researchers is necessary because researchers play a key instrument in digging information in depth and detail.

This research was conducted at Public Islamic School Malang 1 which is located at Jalan Bandung Malang City. Sources of data in this study using primary and secondary data. Primary data were obtained through a series of interviews with principals, classroom teachers, parents, madrasah committees, and parents' associations. Meanwhile, secondary data obtained through documentation and observation studies which then analyzed and used as supporting evidence.

The data collection procedure in this study used three techniques: in-depth interview, observation, and documentation study. Meanwhile, to analyze the data using three stages of reduction, display, and verification (inference) data. The stages are used to select and filter information that fits the research focus so that it can be concluded in accordance with the information obtained. Data checking is required to ensure correctness of information obtained by the researcher. Checking the validity of this research data includes three activities namely, extension of participation, triangulation, and persistence of observation.

\section{RESULTS AND DISCUSSION}

The Partnership considers all parties having an interest in the school as a party that can be empowered and able to assist the school in order to improve the quality of education. Based on data analysis, the following research results are obtained.

\section{Parent and School Partnership Model}

There are various models of partnerships between parents and madrasah in realizing quality education, namely: (a) parental education; This partnership model essentially wants to help parents in building awareness of children's education, among 
them by developing a conducive home learning environment (safe, comfortable and fun); Assisting or assisting children while studying at home; Gaining a correct understanding of the child's condition and possible efforts; Enhancing positive roles and parenting responsibilities in addressing child problems; and promote more harmonious cooperation between parents and schools in helping children's problems; (b) voluntary activities; This model aims to channel the aspirations of each party in supporting and helping the progress of children's education, the form of this model are: accompaniment of children while following the race, preparing everything that the child needs in learning, helping madrasahs in Madrasah birthday celebrations, field trips preparations, and other voluntary activities; and (c) family model; This model is more focused on the pattern of school relationships and parents as a whole within the scope of large school families. One form of this model is embodied in family gathering activities.

Parent-madrasah partnerships aim to achieve quality education. When a community decides to form a partnership, it is important to understand the importance of each party, the understanding in achieving the goals, and be familiar with the environment.

The results of this study are in line with what [1] says, their involvement (parents) can help prepare everything their sons and daughters need as long as, even after school lessons. Parents can help classroom teachers explain specific subjects according to the skills they have [11]. In the meantime, [12] presented his research findings that the guardian plays a role among teachers as substitute teachers and facility providers.

The involvement or partnership of parents and school in education by [8] will provide benefits for the students themselves, the community, teachers, and schools. The benefits of parental involvement in education for learners include: (1) learners tend to benefit more without discrimination between ethnicity and background of economic status, or parental education level, (2) learners generally achieve rank, grade and attendance Better, (3) learners consistently complete their homework, (4) learners become more disciplined and show higher motivation to go to school, (5) positive attitudes of learners to school often give results Improved attitudinal attitudes at school and rarely violate the prevailing regulations, (6) students who are placed in remedial classes are reduced in number, and (7) learners coming from different cultures tend to do better if the parents and labor Educators work together to bridge the cultural differences that exist in the family and school environment.

\section{Strategy for Building a Partnership with Parents}

Strategies that schools can do to build partnerships with parents include: (a) Strengthening Two-Way Communication; is intended to get information and input about the development of learners, both from family to school and vice versa. Communication is done by the school to parents through various forms and media. For example, regularly written information through liaison books, regular classroom parent meetings, parent classroom communication, and communication media such as short messages (SMS) and other social media; (b) Strengthening Parent Associations through Class Societies; establish parent associations in each class in order to facilitate communication between parents per class and teachers in preparing children for learning. While the classroom co-ordinator will be the communication link with the madrasah and the madrasah committee. Through classroom kinship, teachers get help from parents in the learning process at madrasah; (c) Provision of Excellence Madrasah Programs; madrasah efforts to build partnerships with parents in improving the quality of education in the form of making madrasah programs that attract parents, including: field trip program, outbound, madrasah anniversary celebration, and celebration of the big day religious/national; and (d) Creating a conducive madrasah climate for partnership with parents, through friendly attitudes to parents, being patient in serving students and parents, empathizing with parents, when parents come to madrasah warmly welcomed, not installing Sad face, and greet parents with a smile, and certainly involve parents in preparing madrasah programs

Education is a shared responsibility between government, community, and family (parents). Children learn and grow in the family, school, and community environment. When there is a strong linkage between school, family (parents), and community, and involving them actively helping the learning and development of learners, it will have a positive impact on improving the quality of education. The results of [4] indicate that parents 'participation is positively correlated with children's learning achievement and parents' satisfaction with students. [3] states in several studies the results are very convincing that the involvement of school residents, including parents is very positive to support the successful implementation of a policy. While [6] asserted that the active involvement of parents brings a positive impact on student upgrading. Without participation or support from parents, education (school) will not work with maximum [7].

The results showed that the strategies undertaken by schools in building partnerships with parents, include: (a) strengthening two-way communication, (b) strengthening parent associations through classroom associations, (c) providing excellent school programs, and (d) ) the creation of a conducive school climate. The results of this study are in line with the opinion of [10] that in an effort to empower parent participation or develop partnership between schools and parents, schools need to pay attention to the principles, among others: (1) the program must be easy to understand and implemented , (2) sensitive to the aspirations of society in this case are the parents of the students, and (3) the ideas contained are communicated simply and clearly.

School and parent partnerships can be effective, where schools can communicate with parents 
clearly and often [1]. Communication is one of the most crucial means to build good relationships or partnerships with parents. Therefore, schools should allow sufficient time to communicate regularly with parents [7]. There are several things that need to be done by the school in improving the intensity of communication ties with the parents of students, such as through the media: letters, websites, school magazines, school bulletins, phone and other social media such as whatshap, blackberry massanger, and line). Other things that can be done by the school in empowering the participation of parents with effective communication [13].

[1] argues that managing partnerships with parents, can take place effectively when schools pay attention and develop the principle: "... (1) create schools that are open, helpful, and friendly; (2) reward them Has shown dedication and contribution to the advancement of education in schools ..." ". The same thing was presented by [7] that "the attitude that needs to be developed in developing a conducive school climate, among others: being friendly, flexible, open, enthusiastic, empathetic, patient, and respectful to others".

\section{CONCLUSION}

The results of the study concluded that: (1) parent-school partnership forms, including (a) parental education, (b) voluntary activities, and (c) familial models; And (2) strategies for building partnerships with parents, through: (a) strengthening bilateral twoway communication between parents and madrasah, (b) strengthening parent associations through classroom associations, (c) providing excellent school programs, and (d) the creation of a conducive madrasah climate for the ongoing partnership between madrasah and parents.

\section{REFERENCES}

[1] Bacharach. S. B. 1990. Education Reform: Making Sense of It All. Boston: Allyn and Bacon.

[2] Depertemen Pendidikan Nasional. 2007. Pendidikan dan Pelatihan: Manajemen Hubungan Masyarakat dalam Pemberdayaan Masyarakat. Jakarta: Ditnaga Ditjen PMPTK.

[3] Duke, L. D. \& Canady, R. L. 1991. School Policy. New York: McGraw Hill Inc.

[4] Herman, J. L. \& Yeh, J. P. 1983. Some Effective of Parent Involment in School. Urban Review 15 (1): 1116.

[5] Hewison, J. \& Tizard, J. 1980. Parental Involvement and Reading Attainment. Brithis Journal of Education Psychology, Vol.50, Part 3, hlm.209-215.

[6] Keith, S. \& Girling, R. H. 1991. Educational, Management, and Participation: New Directions in Educational Administration. Boston: Allyn and Bacon.

[7] Kusmintardjo. 2010. Manajemen Keterlibatan Orang Tua dalam Pendidikan. Manajemen Pendidikan, Volume 23, Nomor 2, September 2010 (195-203).

[8] Olsen, G. \& Fuller, M. L. 2003. Home-School Relations: Working Successfully with Parent and Families. ( $2^{\text {nd }}$ ed). Boston: Allyn and Bacon.
[9] Preedy, M. (Ed). 1993. Managing The Effective School. London: The Open University.

[10] Rebore, R. W. 1985. Educational Administration: AManagement Approach. Enliwood Cliff, New Jersey: Prentice-Hall Inc.

[11] Reynolds, D., Bollen, R., Creemers, B., Hopkins, D., Stoll, L. \& Lagerwejj, N. 1996. Making Good Schools: Linking Schools Effectiveness and School Improvement. London: Routledge.

[12] Riyani \& Mantja, W. 2008. Peran Orang Tua dalam Membantu Pembelajaran Anak di Rumah. Jurnal Ilmu Pendidikan, 21 (1): 13-26.

[13] Rohiat. 2010. Manajemen Sekolah: Teori Dasar dan Praktik. Bandung: PT. Rafika Aditama

[14] Rugaiyah. 2012. Pengembangan Komptensi Kepala Sekolah dalam Meningkatkan Mutu Pendidikan. Artikel dalam Prosiding International Conference Educational Management, Administration and Leadership. Malang: Jurusan Administrasi Pendidikan.

[15] Tilaar, H. A. R. 2000. Paradigma Baru Pendidikan Nasional. Jakarta: Rineka Cipta. 